\title{
On the Comparative Anatomy of certain Species of the Genus Christisonia
}

\author{
W. C. WORSDELL.
}

With Plates V and VI.

HREE species of the genus Christisonia were investi-
gated: two of these, C. bicolor, Gardn., and C. subacaulis, Gardn., occur in Ceylon, the third, C. neilgherrica, Gardn., in the Neilgherry Mountains of India. They are parasitic plants. As may be inferred from their mode of life, they are of a reduced or modified type of plant-structure, as regards the vegetative parts. These latter consist principally of a branching, subterranean, rhizome-like structure, which is perennial, persisting from year to year in the substratum, and obtaining nourishment by attacking the roots of the Bamboo or Strobilanthes, amongst which they penetrate and intertwine. From the underground parts are sent up the short stems at intervals along the surface, which at first bear scale-leaves, and eventually, when mature, a number of flowers at the summit (Fig. 1). The growth of the aerrial parts is very rapid: within a fortnight the seeds are shed and the stems and fruits (in C. subacaulis, Gardn., at least) decay away in a mass of mucilage.

[Annals of Botany, Vol. IX. No. XXXIII. IMarch, I895.] 


\section{I04 Worsdell.-On the Comparative Anatomy of}

As regards the subterranean parts, it is at first rather difficult to determine what their morphological nature really is, whether they are roots or stems; externally they have very much the appearance of underground stems or rhizomes, and, moreover, the anatomy of this organ in one of the species (C. subacaulis, Gardn.) afforded no evidence either way, as, owing to the parasitic habit of the plant, the typical structure had become considerably modified and obscured; many of the apical parts also showed no evidence of any root-cap. It was only by the occurrence of a typical root-structure in the central cylinder of $C$. bicolor, Gardn., and by the discovery, in both species, of a genuine root-cap at the apex, that the real nature of this organ was eventually decided upon. The absence of any foliar appendages also confirms this decision.

These roots anastomose together by fusion of adjacent parts so as to form a complex network (Fig. 2). This may be compared with the similar phenomenon in the roots of Ficus and Clusia, and also in the lower plants, e.g. Fungi; and serves, perhaps, to ensure a better distribution of nutriment throughout the root-system. In C. subacaulis, Gardn., tuberous portions of the root occur here and there: they are always the centres of attachment between the parasite and the host, the haustoria arising here (Fig. 3). In C. bicolor, Gardn., these tubers are absent, or the root, at corresponding places, only becomes swollen to a slight extent. Where they occur the tubers appear to serve as stores of nutriment and as centres from which root-branches and stems grow out in various directions.

\section{C. bicolor, Gardn.}

This plant is parasitic on the roots of a species of Strobilanthes. Portions of the parasite are attached as tiny plants here and there on the finer branches of the host-roots, but they may also be found attached to the thicker portions. The long, rhizome-like branches of the root also send out haustoria where they happen to be in contact with a host-root.

This plant is much more slender in all its parts than 
C. subacaulis, Gardn., which it more nearly resembles than C. neilgherrica, Gardn. It is, however, of a more typical and normal structure than the former species, and for this reason I have chosen to describe it first.

The roots anastomose together to form a complex system, but in a less striking degree in this plant than in C. subacaulis, Gardn. The tubers, so characteristic of the latter plant, are absent in this species.

The roots may be described as long, wiry, rhizome-like organs, of small diameter, which send out at frequent intervals on the surface round, knob-like structures. These are the young stems. The roots branch freely and grow rapidly in all directions in the substratum.

\section{Anatomy of the Root.}

In a transverse section of the root (Fig. $4 b$ ) the outer layer of cells is seen to consist of small elements with thick outer walls, usually of a brownish colour, with granular matter, probably soil, attached to them.

The cortex is built up of rather large cells, which in the outer portion are compactly arranged; the inner portion of the cortex consists of much looser tissue, the rounded cells exhibiting very numerous intercellular spaces. Nearly all the cells of this region have their walls extremely thickened or mucilaginously swollen where they border on an intercellular space, although the thickening may sometimes occur on opposite sides of the common wall of two cells (Fig. $4 b$ ). These thickenings were found to stain with methylene-blue, Hoffmann's blue, and aniline violet; they are more or less half-moon or crescent-shaped, with a very convex surface towards the cell-cavity. The mycelium of a fungus was seen to occur occasionally in the cortex. The cells are often full of starch-grains.

Closely surrounding the central cylinder is a zone, one to three layers thick, of small stone-cells, of which some are considerably larger than the rest; the root, however, exhibits some variation in the number of these elements in this region. 


\section{Worsdell.-On the Comparative Anatomy of}

There is a distinct endodermis present, which is clearly differentiated on treatment of the section with strong sulphuric acid. It consists of a slightly sinuous layer of small, compactly-arranged cells immediately outside the cylinder.

The pericycle is not so clearly distinguishable, and appears as if interrupted here and there by phloëm-elements. It is one layer in thickness. There is considerable variation in different roots in the structure and general appearance of the central cylinder. In some roots the typical radial arrangement is very clear; the small protoxylem elements lying at three, four, or five points on the periphery, entirely separating the phloëm into as many groups (Fig. $4 b$ ); in others, however, the phloëm-groups show a tendency to unite continuously to form a peripheral ring. The central part of the cylinder is usually occupied by a few xylem-elements and parenchyma; in many roots, however, the entire central part consists of small, compactly-grouped stone-cells, which here, apparently, replace the xylem-elements, the latter having, in these plants, a very rudimentary development. In those roots which are destitute of the central strand of stone-cells, the xylemelements are fairly numerous; in those in which the stonecells occur, they are fewer in number and greater in diameter, the phloëm being also much more developed. Another form of root-structure in this plant is that in which the xylem-elements are considerably larger, more conspicuous, and more numerous than in the ordinary type; in such roots the phloëm is developed to a remarkable degree, and occupies, not only the peripheral portion of the cylinder, but also the entive central region, where the pith would normally occur. This seems a strange occurrence, but the elements composing the central portion had an appearance identical with those of the periphery, consisting of sieve-tubes and companion-cells ${ }^{1}$. The phloëm-elements are, like those of the xylem, much larger and more conspicuous than in the

1 C. Scott and Brebner, Anatomy and Histogeny of Strychnos, Annals of Botany, Vol. iii., I889. Also Scott and Sargant, On the Pitchers of Dischidia rafflesianca (Wall.), Annals of Botany, Vol. vii., I 893 . 
normal form. The xylem-elements of the root may be either tracheides or vessels; both kinds of elements occur indiscriminately, and are rather difficult to distinguish the one from the other. If the element be a vessel, the perforation may either occupy the whole surface of the terminal wall or the latter may be reticulately thickened, the perforations, which are of varying sizes, occurring between the reticulations. That tracheides, as well as vessels, are present, was inferred from the occasional occurrence of a delicate membrane stretching across the terminal wall, its presence being indicated by the minute granules scattered about on the latter; this was found between two xylem-elements, as well as where one of these abutted on a parenchyma-cell.

The phloëm offers nothing specially worthy of remark; it consists of sieve-tubes, companion-cells, and parenchyma.

In longitudinal section the cells of the external layer appear narrow and elongated, and this is also the character of the outer cortical cells. The inner cells of the cortex are shorter and broader, and usually contain starch. Where there are stone-cells surrounding the central cylinder, these are of varied shapes; they are usually short and rather narrow, sometimes quite square and broad, sometimes irregular in shape. The phloëm parenchyma consists of broad, rather long cells, often filled with dense protoplasmic contents with large vacuoles. The sieve-tubes are well developed, their terminal walls are either transverse or slightly oblique ; the sieve-plate with its perforations is clearly distinguishable, and there is a wellmarked callus-layer below.

The companion-cells are numerous: they are either small elements, extending only part of the way along the sievetube, or they may be narrow elements, cut off along the whole mature length of the former.

On the periphery of the cylinder are seen the long, spirally thickened protoxylem-elements, which are very narrow in diameter. The later-formed xylem-elements are usually quite short; most of them show some amount of slidinggrowth, as the terminal walls are often oblique. As might, 


\section{Io8 Worsdell.-On the Comparative Anatomy of}

perhaps, be expected from the reduced nature of this tissue, the vertical rows of xylem-elements are frequently interrupted and cut off by parenchyma, the continuity of the series being maintained by an oblique connexion with other elements of a different vertical row - the perforation between the two connecting elements being thus often in their lateral walls. The terminal walls of these elements, usually seen in section, appeared to show in nearly every case evidence of one or more perforations. With the exception of the protoxylem, all the elements are reticulately thickened.

The stone-cells, occupying the centre of some roots, are narrow, much elongated elements; being so conspicuously developed here, I may suggest for them a function, which consists in resisting longitudinal tension-strains set up by the separation, on maturing of the flowering-stems, into distinct plants of the subterranean root-system.

The apex of the root (Fig. II, C. subacaulis, Gardn.) shows a differentiation into three layers, viz. plerome, periblem, and a common layer for the dermatogen and root-cap. The apices of some roots examined showed no distinguishable root-cap whatsoever.

Lateral roots arise from the central cylinder, and most probably from the pericycle, though their exact origin from this layer was not ascertained. The youngest stage observed was where the young organ was about two or three layers of cells distant from the cylinder. As the young root gets older its origin becomes more obscure, as its cortical cells, though mostly traceable in radial rows back to the central cylinder, appear at the same time not sharply defined against those of the parent-root; the sharp line of demarcation between the young root and the ground-tissue of its parent extends only a short distance from its tip (Fig. I9) on either side; this gives rise to an appearance as though the lateral root had a cortical origin, instead of a pericyclic one as is probably the case. Fig. I 9 shows a section of a lateral root at the stage where it is about to burst through the external layer; it is seen to possess a well-marked root-cap $(r c)$ of a single layer of 
cells. After the young root has emerged from the cortex of its parent and begins to grow rapidly in thickness nearly all traces of its endogenous origin become obliterated, indeed it is often very difficult to tell at the mature stage whether it is with a case of exogeny or endogeny that one has to deal; it was only after careful scrutiny and the discovery in most, if not all, cases of a short flap of two or three layers of cortical cells (the evidence of rupture), that the typical endogenous origin of these root-branches was determined. In the development of a branch, the cortex of the parent-root often becomes very much bulged out, so that the flap just mentioned comes to lie at some distance along what appears at first sight to be the basal part of the lateral member itself. The place of origin of a rootlet, at the stage shown in Fig. 19, is indicated by minute swellings on the external surface of the root, caused by the raising of the cortex at those points.

The stem, as has been stated above, arises from the root. It is of endogenous and probably also of pericyclic origin. Like the lateral root, its origin becomes obscured as it advances in age, so that it gives the impression of arising from the second or third layer of the cortex, reckoning from the outside. An examination of Fig. 20, however, which is drawn from two sections of the root of $C$. subacaulis, Gardn., will reveal pretty plainly the real origin of this organ from the region of the central cylinder. It is a much broader outgrowth than the young root, with a flatter and broader apex, which region is seen to be covered by the first two young leaves $(l)$. Unlike the root, its sole mode of piercing the cortex is the mechanical one of pushing a path for itself through the surrounding cells. As the stem grows outward and finally bursts the outermost cortical layer, the successive young foliar organs are rapidly produced; these give the rounded, knob-like character to the young stems as they appear scattered on the surface of the root. When the young stem has attained to about one-fourth of an inch in length it often gives rise to adventitious structures, which are roots and arise endogenously; they grow down into the substratum. 


\section{Io Worsdell.-On the Comparative Anatomy of}

As above stated, these plants are parasites; they obtain their nourishment, therefore, by means of haustoria, which penetrate the living tissues of other plants; the roots serve, not, as in most other plants, for the absorption of water and mineral substances from the substratum, but as storehouses of nutriment, for the production of the floweringstems, and for the perennation of the plant and the extension of its area from year to year. The stimulation to formation of a haustorium is caused by direct contact of the root with that of the host-plant, which, in this case, is a species of Strobilanthes. The external layer of cells at the point of contact divides in places, and the cells for some distance on either side become elongated radially, while they become filled with dense protoplasmic contents, and exhibit conspicuous nuclei; at the same time, the cortical cells immediately below this layer divide rapidly in several directions, while a few divisions occur in those more deeply situated. As a result of this, the initial stage of haustorial formation, the cortex becomes considerably bulged out, as seen in transverse section (Fig. 21). A few of the cells, on either side of the point of contact, grow out into hair-like papillae, which possess a thick cell-wall and dark-brown contents with a prominent nucleus. These grow towards the host-root. The portion of the cortex at the point of contact at length, by repeated divisions in the cells, grows out as the haustorium. This new organ, by the aid of its external layer, dissolves its way by fermentative action into the tissues of the Strobilanth. That portion of the root of the parasite around the point of penetration becomes applied firmly to the surface of the attacked root, the cells in contact being much elongated and more or less contorted in shape, with dense contents. As the haustorium advances inwards towards the centre of the host-root, the effect of its work of absorption of foodsubstances from the living tissues of the host is shown by the distinct zone of cortical cells extending from the haustorium to the central cylinder of the parasite, which are densely filled with starch-grains (Fig. 22); this zone is best 
seen in a section not quite median, which does not pass through the vascular strand; the latter becomes differentiated as the haustorium grows out from the cortex, and eventually, when it reaches the central cylinder of the host, a continuous chain of xylem-elements is laid down, extending from the central cylinder of the root of the parasite, through its tissues and those of the haustorium, to where a direct union is effected between the vascular tissue of the haustorium and that of the central cylinder of the host-root. The main portion of the haustorium is built up of slightly elongated cells, with dense contents and conspicuous, large nuclei. Their function may consist in the conduction and storage of proteid matter. No sieve-tubes were anywhere discovered. The haustorium sometimes occupies almost the entire diameter of the host-root and destroys a large area of its tissues. The haustoria attached to one piece of root were all completely filled with dark fungus-spores and hyphae, which also occupied part of the tissues of the host-root, as well as a few of the cortical cells of the root of the parasite; they were sufficiently numerous to interfere with the work of the haustorium in absorbing food from the host.

From the above description of the development of the haustorium, it will be seen that it is of exogenous origin (Fig. 22); there is no evidence to show that it arises from any of the internal layers of the cortex; it appears simply to be formed by a direct outgrowth from the surface of the root, as is the case in the roots of Rhinanthus, and not in the mode described for Cuscuta ${ }^{1}$ and others.

\section{Anatomy of the Stem.}

A transverse section of the stem shows an almost complete ring of vascular tissue; the band is broken at the place of insertion of the leaf-trace bundles, two or three of which

${ }^{1}$ On the Structure of the Haustoria of Phanerogamic Parasites, by G. J. Peirce ; Annals of Botany, Vol. vii. No. 27. A Contribution to the Physiology of the Genus Cuscuta, by G. J. Peirce, Annals of Botany, Vol. viii. No. 29. 


\section{2 Worsdell.-On the Comparative Anatomy of}

appear rather further on the outside. The vascular tissue is ensheathed, on both inside and outside, by a thick zone of stone-cells, which gives a characteristic appearance to the structure. The epidermal cells are small. No stomata were observed. The outer part of the cortex consists of rounded cells exhibiting small intercellular spaces. The bundles of the central cylinder are arranged in close contact one to another, being separated only by a narrow zone of parenchyma. Both xylem and phloëm are fairly well developed. A distinct cambium is present, giving rise to slight secondary thickening in the ring. An endodermal layer could not be clearly distinguished; only a few cells here and there showed evidence of having cuticularized radial walls. The cells of the pith are full of starch.

In a longitudinal section the cortical cells appear compactly arranged, with small intercellular spaces between them, in which a fungus, which we shall find to be a constant feature in the root of $C$. subacaulis, Gardn., rather sparingly occurs. The stone-cells of the cortex and the pith are more or less elongated and rectangular, or have pointed ends. The remaining pith-cells are rather elongated and full of starch.

The stems bear scale-leaves, which occur either in pairs decussately arranged or alternately; there is nothing special to mention about the anatomy of these.

A few flowers are borne at the extremity of the stem, each in the axil of a bract (Fig. I).

\section{Structure of the Flower.}

The calyx, which is pink in colour, is gamosepalous, with five, free, equal segments above; it is considerably shorter than the corolla. The latter is gamopetalous, consisting of a tubular portion and five, free, irregular segments above, which go to form a sub-bilabiate structure.

The cells of the petal are loosely arranged, and there is evidence of sliding-growth amongst them; the epidermal cells are slightly papillate on both surfaces. 
The calyx and corolla both bear short secretory glands. These glands supply the mucilaginous covering to these parts, which serves, perhaps, as a protection against the attacks of crawling animals, which must abound in the neighbourhood of these plants.

The stamens are four in number. They are epipetalous. The four anthers are united together. A transverse section of the anther shows in the young stage a bilocular construction, each loculus being more or less crescent-shaped, owing to the projection into the cavity of a broad, conical band of sterile tissue from the connective. A single layer of radially-elongated tapetal cells lines the cavity. The pollen-mother-cells divide tetrahedrally to form pollen-grains; occasionally a cruciate division was observed. The external layer of the wall of the anther consists of rounded, thick-walled cells; when the pollen-grains are ripe, the partition-wall between the two loculi breaks away, so that the anther thus becomes unilocular; the soft-celled inner layers of the anther-wall shrivel up, while the external layer of thick-walled cells remains intact, and scarcely ever broke when the anther was cut.

The stigma is a wide, expanded surface, covered with papillate, hair-like cells, which are much elongated and pointed; their tips, however, being obtuse and rounded off. The subjacent tissue is quite loose.

The style possesses two bundles on opposite sides of a central cavity, which in the upper part of the organ is filled with much-elongated cells whose cavities are widely separated by their mucilaginously-swollen walls.

The ovary consists of two carpels, and is unilocular throughout. The placentation is parietal, consisting of two opposite bi-partite placentas expanding into the ovarian cavity and almost filling it. They bear over their surface very numerous anatropous ovules, which are embedded in mucilage and are extremely small. 


\title{
I 4 Worsdell.-On the Comparative Anatomy of
}

\author{
C. subacaulis, Gardn.
}

This plant is much more reduced than either of the two other species investigated. It is parasitic on the roots of the Bamboo, amongst the thick, tangled masses of which its own roots vegetate in a mutually anastomosing network. The subaërial part is extremely mucilaginous, much more so than either of the other species; at the end of the season this character becomes more marked, till the whole becomes resolved into a decaying, mucilaginous mass. A purple substance occurs throughout the entire plant, especially in those parts active in secreting a ferment.

The general morphology of this plant is similar to that of $C$. bicolor, Gardn., so that I may at once proceed to describe the anatomy.

\section{Anatomy of the Root.}

As seen in a transverse section, the external layer of the cortex consists of small cells, usually with conspicuous nuclei, and thick brown walls, both on the inner and outer sides. The main cortical tissue consists, especially in its inner portion, of large, rounded cells, containing, usually, very numerous compound starch-grains. Owing to the loose arrangement of these cortical cells, there is a conspicuous intercellular system; in the spaces thus formed a fungus occurs; it is constantly present, as shown by its reappearance in every root or portion of root examined. The exterior surface of the cell-walls are lined with its hyphae, from which conidia-like bodies jut out into the space; these arise from an excessively short stalk, from which two, three, or a larger number of conidia are abstricted off (Fig. 26); these fall on the wall of the cells (Fig. 27). But, besides these smaller bodies thus formed in such numbers, there may be observed larger, spore-like bodies, of a dark brown colour; these appear each on the end of a stalk and inclined to one side of it, that portion of the stalk immediately below it appearing rather swollen. At more advanced stages two of these 
neighbouring or even opposite out-growths or stalks are seen to fuse together at the apex, where a rounded body, like those already described, appears, which becomes at length much swollen, and from which, as it eventually disintegrates, short filaments are seen emerging. It is possible that we have here a case of zygospore-formation in the fungus. If the sections are placed overnight in a solution (one per cent.) of gold chloride, then washed, and allowed to remain some time in citric acid in the sunshine, the protoplasm of the fungus stains a dark purple colour. Although the fungus is essentially intercellular in its distribution, hyphae were occasionally observed in some of the cortical cells, and are sometimes seen passing through the pits into a stone-cell.

An endodermis could not be distinguished; it would appear to be more or less interrupted by the aggregation of stonecells in the region where it is usually sought. On treatment of a section with strong sulphuric acid the whole of the cortex is destroyed with the exception of the stone-cells, two or three of the outermost layers, and the fungus in the intercellular spaces. The cell-walls bordering on these spaces appear also uninjured, as if they were cuticularized; this they possibly may be, in order to prevent the inroads of the fungus into the cell-cavity.

We come next to the structure of the central cylinder; in this plant its typical radial arrangement is quite obscured, owing to the greater development of the phloëm, which here forms a continuous outer zone, and the reduced and rudimentary state of the xylem, which often consists of only a few elements occupying the centre of the cylinder or scattered irregularly here and there amongst the parenchyma (Fig. $4 a$ ); sometimes one or two elements can be traced further out between the phloëm-elements, and these appear to represent the protoxylem, though no elements of small diameter, so characteristic of the protoxylem elsewhere, are present. From this very modified structure it thus becomes difficult or impossible to ascertain what is the real arrangement of the cylinder. The xylem-elements consist of both 


\section{in Worsdell.-On the Comparative Anatomy of}

tracheides and vessels, the terminal walls having sometimes one or two conspicuous perforations, at other times only a few scattered pits. Parenchyma occurs abundantly around and among these elements. Sieve-tubes, companion-cells, and phloëm-parenchyma are irregularly arranged in large numbers, forming a well-developed tissue.

The stone-cells, which constitute a very characteristic tissue in the root of this plant, are of considerable diameter. They are scattered irregularly throughout the cortex; round the cylinder they occur in greater quantity, often in groups of several together; here they may have very thick walls.

A small portion of the root, chiefly some of the outer cortical cells, is often injured or destroyed by the invasion of a fungus, whose dark brown spores fill the cells in large numbers.

In a longitudinal section the cortical cells of some roots appear elongated; in most, however, they are isodiametric. The intercellular spaces are often filled with a brown substance, which is probably connected with the fungus above described.

The sieve-tubes and companion-cells are very abundant; the former are of various sizes; of these the innermost are quite short, and differ from the companion-cells which are cut off from them only in shape; those further to the outside are much longer - they have either transverse or slightly oblique terminal walls, on which are several sieve-plates; there is always a conspicuous callus-layer below the plates, which stains well in aniline-blue and Hoffmann's blue. Sieve plates also occur on the lateral wall between two sieve-tubes; none were observed between the latter and companion-cells. The younger sieve-tubes have protoplasmic contents and a conspicuous nucleus.

The companion-cells are cut off from the sieve-tube either in regular, uninterrupted, vertical rows of narrower or broader cells or they may occur isolated, with a curved wall bulging out towards the cavity of the sieve-tube, and having more or less pointed ends. They are either quite small elements 
or of considerable size, having usually very dense protoplasmic contents in which occur many large vacuoles. The mode in which they are cut out of the sieve-tube often gives that element a peculiar bent and curved appearance. There is frequently an appearance as if a companion-cell was cut off on each side of the same sieve-tube ; in some, these three cells are equal in length, the two lateral ones having denser contents than the middle one; in others, the middle cell is longer and more trumpet-shaped, overtopping the two lateral ones at either end and expanding above them. This suggests that the middle segment of the original procambial cell has grown in length to become the sieve-tube, while the two sister-segments remain behind as companion-cells. The sieve-tubes are often arranged in regular radial rows for some distance.

The parenchyma-cells are wide, elongated elements.

The xylem-elements are usually very short, with transverse or sometimes slightly oblique terminal walls; often they are more elongated. They have reticulate thickenings. Their course is the same as that described in the last species. On the outside, nearest the phloëm, are the protoxylem-elements, which are more elongated than the others, while their thickenings are partly spiral, partly reticulate; they are not very typical for protoxylem, but are rather transitional in character between this and the later-formed elements. The perforations in the terminal walls of the vessels are in this plant distinctly seen in sectional view.

The outermost stone-cells, scattered in the cortex, are short and more isodiametric in contour, and are isolated. Those immediately surrounding the central cylinder are usually very much elongated, thick walled, and massed together in groups.

In some places the roots show a slight swelling, which is the commencement of the large, thick, tuberous portions of the root which are so common.

These tubers occur at frequent intervals in the root and are very characteristic of this species. If a section be made 


\section{8 Worsdell.-On the Comparative Anatomy of}

through one of these tubers so as to pass through the rootcylinder, this latter will be seen in one part of it in either transverse or longitudinal section. The cortex has the same character as that of the root, containing starch-grains, \&c. Besides the root-cylinder there will be seen one, two, three, or many bundles, which have a peculiar and striking appearance ; they are usually seen in transverse section; in the centre are a few obscure xylem-elements; surrounding these is a small zone of cells with very dense protoplasmic contents and conspicuous, large nuclei. These last-named cells are more or less isodiametric and angular, and when seen in longitudinal section are scarcely elongated; the cells on their immediate outer limit, however, are rather more elongated and have not such dense contents. Outside these, again, is a conspicuous zone of cells with rather larger lumen and much clearer contents, containing much smaller yet distinct nuclei. Then follows an irregular grouping of cells, surrounding the last zone, with prominent dark nuclei and dense proteid contents. The first-described zone of dark-coloured cells, with the central xylem-group, represents the bundle; this is always accompanied, however, by the two zones of cells last described (Fig. 5). These 'proteid-bundles' traverse the tuber in various directions, and may be seen running parallel to the root-cylinder or crosswise and at right angles to the latter. In some tubers all the cells of the ground tissue have very conspicuous nuclei; while in most this is not the case, though the cells of the external layer are always thus characterized. Large agglomerations of stone-cells also occur throughout the cortex.

In every case, when one of these tubers is examined, it will be seen that there is a portion of a Bamboo-root attached to it at some point (Fig. 3). If a series of sections be taken through a tuber, the 'proteid-bundles' can be traced till they eventually bend outward, and, two or more fusing together into one, enter a haustorium which is penetrating the hostroot. Thus, the haustorial bundle, on entering the tuber, instead of passing directly to the central cylinder, branches, 
usually, into two or more diverging bundles, which dip away into the cortex. These 'proteid-bundles,' from the above description of their structure, perhaps act as storehouses for the spoils of the haustorium. By traversing the greatlyenlarged cortex in all directions they aid in distributing the nutriment through the tissue of the tuber so formed, thus supplying the young lateral roots and stems, which so frequently have their birth in this organ, with abundance of food-substances. The xylem of these bundles eventually unites with that of the root-cylinder, which-so filled does the tuber become with the 'proteid-bundles'-is often scarcely distinguishable in some obscure corner. The tuber thus becomes the most important centre of the plant, as the place of origin of the haustorium (which I am about to describe), the storehouse of the food-substances derived by its means, and the birthplace of many young roots and stems.

The haustorium is of exogenous origin, being formed by a superficial outgrowth from the tuber. The Bamboo-root may be attached for about an inch along the surface of a tuber (Fig. 3), several haustoria being sent into it. Most frequently it was found attached at a single narrow point with a single haustorium attacking it. The cells of the external layer of the root adjacent to the haustorium, or those at all contiguous to the host-root, some of which are produced into papillae, or grow out together to form multicellular protuberances, have, usually, thick outer walls of a dark-brown tinge. They serve to attach the root of the parasite to that of the host.

The lateral and apical cells of the haustorium have purple contents and conspicuous nuclei, and are very active in dissolving the cortical cells of the host; the latter, surrounding the haustorium, are often densely filled with starch-grains; these also occur in numbers in the cortical cells of the haustorium, and also become stored up in the tuber. The xylem of the haustorium consists of slender, narrow, spirallythickened elements; surrounding these are slightly elongated cells with dense protoplasmic contents and very prominent 


\section{I20 Worsdell.- On the Comparative Anatomy of}

nuclei; no sieve-tubes were ever seen. There is a well-marked cortical region in the haustorium of this species.

Having entered a Bamboo-root, the haustorium may either grow straight through the cortex and penetrate directly, with its apex, the central cylinder (Fig. 6), or, having entered the cortex of the host, may branch, the branches bending at right angles to the cylinder or running parallel to it through the cortex (Fig. IO). As a haustorial branch thus pursues its course through the inner region of the cortex, some of its lateral cortical cells in contact with the central cylinder acquire dark purple contents, and begin to dissolve the cells lying against it ; this fermentative action goes on until a cell, having opened out a cavity in the conducting-tissue of the host, grows out into it as a papilla or sucker; this cell has fine granular contents, and dark lines in the convex portion of its wall, which look like pits; by these lateral suckers a large portion of the cylinder becomes destroyed (Figs. 7 , 8, 9). In Fig. 6, which represents a haustorium directly penetrating the central cylinder of the host, the xylemelements and their accompanying proteid-cells are seen to be in contact with and spreading among the conducting elements of the cylinder.

The lateral roots are of endogenous origin, as indicated by the projecting flap of cortical cells, already referred to, nearly always found on either side of a lateral member. No young stages of lateral roots were seen in this plant. In some instances there is great difficulty in determining whether the branch is of endogenous or exogenous origin, the appearance being greatly in favour of the latter mode. There seems little doubt, however, that the endogeny becomes more or less obscured as the branch advances in age and thickness.

What has been said of the root-apex in describing the last species, applies equally in this case (Fig. II). I need only mention that some apices appeared to be destitute of a root-cap.

The anastomosis of these roots is a curious phenomenon. At the point of contact of two roots the cells of its outermost 
layer in each organ behave just as the same cells do when in contact with a Bamboo-root, viz. they become much elongated radially, acquire purple contents, and brown, swollen walls, while a ferment is secreted which destroys the limiting cuticularized wall of each root in places here and there, so that at these points direct fusion between the elements of the two distinct organs takes place. Some of the cells in the neighbourhood of the fusion grow out as papillae which bend round towards the point of attachment. In a section through the point of fusion of two roots, the incompleteness of the union is often seen by the small, often minute, portions of the cellwall, which formed the boundary between the two roots, still remaining, and between which vascular tissue passes from cylinder to cylinder; but in other cases the fusion is complete.

The roots attach themselves to each other in all directions and at every angle, so that an intricate network is formed, as seen in Fig. 2. In this way, those parts of the root-system distant from a tuber are more readily supplied with the nutriment which they need for their work of extension and the building-up of the flowering-stems.

At places here and there on the roots, as well as on the tubers, young stems arise. These are of endogenous origin, being derived from the central cylinder of the root, and probably from the pericyclic layer (Fig. 20).

Their origin becomes obscure as they increase in age, so that, like the lateral roots, they appear to be of cortical origin; the external layer of the root remains intact around the apex of the young stem for some time, becoming very much bent and stretched outward; it finally snaps and gets left behind as a flap of a single layer of cells on either side of the young growing stem. Unlike the lateral root, the young stem has no dissolving action on the cells of its parent-root, but simply pushes its way outward through the cortex; its outward course will, therefore, probably be less rapid than that of the former organ. The young stems are in the form of small, conical elevations on the root, which, in their youngest stages, appear as mere dimples on the surface; a median section 


\section{Worsdell.-On the Comparative Anatomy of}

through one of these shows four or five leaves arching right over a broad, flat apex of small, often purplish, cells.

The stem may attain a length of 6-8 inches, and bear several flowers at its summit. It has usually a very much bent and curved attachment to the root, owing, probably, to the fact of its having originated laterally on that organ, and been forced to bend upward towards the daylight. In its middle portion, about half-way between its attachment to the root and the inflorescence, it sometimes becomes considerably thickened and swollen, tapering off again towards the apex.

\section{Anatomy of the Stem.}

In a transverse section of an adult stem are seen a number of bundles scattered irregularly throughout the ground-tissue; they vary in number and in size. So reduced and modified is the stem of this species, that not only are the bundles irregularly distributed, but the orientation of each separate bundle is no longer normal; the xylem is usually in the centre, surrounded entirely by phloëm; the elements composing the bundle are very scattered; there is a considerable amount of parenchymatous tissue present.

No endodermis could be distinguished in this stem.

The cells of the ground-tissue are exceedingly loosely arranged and much rounded off; they are large in contour and contain much starch. More will be said of these elements in treating of the longitudinal section.

No stomata were observed anywhere on the stem, either in transverse, longitudinal, or surface section.

In some stems stone-cells appear to be entirely absent; in others they are present, surrounding the bundles or in the ground-tissue; but they are not nearly so well-developed as those of the root, being much thinner-walled.

If successive transverse sections are made in the lower part of the stem, near its junction with the root, it will be seen that the bundles become fewer in number and larger, owing to fusion one with another, and also that they arrange themselves 
near the centre of the stem; four or five of these bundles may fuse into a kind of network near the base of the stem, then separate again into three or so, which almost directly after fuse with the central cylinder of the root which is running at right angles to the stem (Figs. 12, 1 2a).

In a longitudinal section the structure of the bundle can be easily seen. The xylem-elements are rather longer and narrower than those in the root; they also undergo rather more sliding-growth, as their terminal walls are usually oblique, and more so than those of the root. The protoxylemelements have usually a very loose spiral, which is often entirely separated from the wall and lies as an almost straight thread within the element; others have annuli, which are rather distant and only just serve to keep the walls from collapsing; these walls are frequently so thin as scarcely to be perceptible.

The phloëm-elements also undergo more sliding-growth. The sieve-tubes have a more oblique terminal wall than those of the root, and have several plates both on the terminal and the lateral walls.

The cells of the ground-tissue are very loosely arranged and more or less contorted in outline, so that wide spaces are left between the cells. The reason for this may perhaps be sought in the fact that a properly-developed intercellular -system is necessary to ensure free access of air for respiration, and this may be correlated further with the absence of stomata on the stem ; it may also be to admit of easy and free transpiration during the rapid growth which the plant undergoes in order to mature its flowers. As a result of the slidinggrowth and contortion of the cells, the greater part of the common wall which connects any two cells, either laterally or terminally, splits at the middle lamella, and thus the two cells become separated. But some parts of the wall split more easily than others; the parts which offer greatest resistance, and remain firm without splitting, cause each cell at that point to be drawn out into a tube owing to the rapid growth which each cell is undergoing; as a result of the stimulus 


\section{I24 Worsdell. - On the Comparative Anatomy of}

from the strain thus set up, the wall at the point of contact of the two cells becomes excessively thickened, and when, at length, the final splitting takes place at the middle lamella, the retreating portions of the cell-wall appear like drumsticks, owing to their great extension and knob-like swelling at the end. The knob often appears as if about to be split off from the rest of the cell-wall. In some sections of older stems the outermost cells are more contorted and show more striking sliding-growth.

In the ground-tissue of some stems examined occur sac-like cells full of dense granular contents.

On the surface of the stem are scattered a large number of mucilage-secreting glands ; each has a stalk of one to three cells and a head of secreting-cells about eight in number (Fig. I3).

The stem bears scale-leaves, which are few in number and alternately arranged. They are large as compared with the size of the stem on which they are borne, and the uppermost bear flowers in their axils. The epidermis of the scaleleaf is covered with numerous stomata. These have a very irregular arrangement, lying in all directions. As seen in surface-view their openings were extremely wide, and their guard-cells long and narrow. The subjacent tissue of this dorsal surface is exceedingly loose; the cells are narrow and contorted, exhibiting extremely large intercellular spaces; the tissue on the ventral side is more compact, with fewer spaces. Mucilage-secreting glands are scattered all over the ventral surface. The venation in these organs is to a great extent parallel. The bundles have the normal orientation.

\section{Structure of the Flower.}

The flowers are borne on rather long stalks in the axils of bracts. The calyx in this plant is a loose, reduced structure, of no definite shape ; it may either terminate in two opposite pointed lobes or it may form a mere sheathing body ending in an acuminate apex. The anatomical structure of the calyx 
is similar to that of the scale-leaf. The corolla greatly overtops the calyx by its long tubular portion, which terminates in five subequal, roundish lobes which are denticulate at the apex. The colour of the corolla is white, its lobes being edged with deep violet. In shape it is funnel-shaped and curved (Figs. I, I 5, I6). A section of the petal reveals a loose ground-tissue, whose cells contain a few starch-grains; some cells are filled with minute fungal spores or conidia whose hyphae are seen in nearly every cell. The epidermal cells have conspicuous nuclei; those of the lower surface are purplish, with dense contents of starch-grains or other granules. Mucilage-glands occur on both surfaces, especially on the outer one, where they produce a thick film of the secretion.

The stamens are four in number (Figs. I $5,16,17$ ). Of these, the two posterior ones have each a peculiar swollen prolongation or spur from the connective, which is equal in length to the anther and deflexed, arising near the attachment of the filament; this spur is of a loose internal structure, with large intercellular spaces, this tissue being traversed by a single small bundle; the structure terminates in a sharp point formed of numerous stone-cells with curious lignified thickenings. Each of the four anthers in this plant is unilocular when mature, though bilocular before the pollen-grains are ripe. According to Wight ${ }^{1}$ and Hooker ${ }^{2}$, each of the anthers of the posterior pair of stamens has one imperfect, sterile loculus, which is spurred or appendaged f from my own examination the spur-like appendage appears as a prolongation of the connective.

In a transverse section of the anther it is seen that the cells of the epidermis, and of one or two of the underlying layers, on the dorsal side of the anther, nearest the attachment of the filament, have lignified spiral thickenings; also in the cavity of the suture on the ventral surface, a few cells of the second layer from the outside have similar spiral thickenings. It is possible that these assist in preventing a rupture of the anther-

1 Wight, Icones Plantarum Indiae Orientalis, Vol. iv. p. 5.

2 Hooker, Flora of India, Vol. iv. p. $3^{2}$ I. 


\section{I26 Worsdell.-On the Comparative Anatomy of}

wall. The short partition, consisting of narrow thin-walled cells, separating the two cells of the young anther, very easily ruptures, the anther thus becoming unicellular.

When the pollen-grains are ripe, the four anthers become united together on their ventral surfaces (Fig. I7) by a thick mass of mucilage, this being secreted by long-stalked glands which occur in large numbers on the dorsal side in the angle between the anther and the filament, as well as on the ventral suture. The anthers, when thus united, are seen to be unilocular, owing to the rupture of the wall separating the two cells.

In a transverse section of the four anthers at this stage, those of the two anterior stamens appear united face to face by a mass of mucilage, the wall of each being broken in the middle and bent inward; those of the two posterior stamens are laterally in contact with each other, the wall of each being unbroken; their faces adhere by mucilage to the anthers of the anterior stamens; the anther-cells of the posterior stamens are usually much more divaricate than those of the anterior ones.

According to Gardner ${ }^{1}$ and others, the dehiscence takes place by an apical pore.

The stigma is a large expanded surface, borne on a long style, which in its upper region is contractile; as a result of this, the stigma, when touched by any object, bends back against the roof of the flower. Amongst the pointed, papillate cells of the stigma pollen-grains are sometimes seen germinating.

The ovary is unilocular throughout. The two bipartite parietal placentas bear a large number of extremely small anatropous ovules, which are embedded in mucilage. The whole tissue of the ovary and its contents are of a deep purple colour.

\footnotetext{
1 Gardner, Contributions towards a Flora of Ceylon, being the description of Christisonia, a new genus of the tribe Cyrtandreae, in Calcutta Jour. Nat. Hist., Vol. viii. p. I53, I 847 .
} 
C. neilgherrica, Gardn.

It is to be regretted that no roots of this species were available for examination, as, owing to the depth at which they grow in the soil, it was found by those who attempted it an almost impossible task to dig them out. As this species is quite distinct from either of the other two, so much so that by some it has been placed in a separate genus, an examination of its root-structure might have been invaluable in helping to elucidate some of the important peculiarities in the other two species.

This plant possesses thick, stout stems of considerable length, viz. about $\mathrm{I} 2$ to $\mathrm{I} 6$ inches. They usually taper from a narrow base up to a very thick and much swollen portion, gradually tapering again towards the summit, where the flowers are borne. The swollen portion of the stem is thickly clothed with imbricating, suborbicular adpressed scales, which in their lower part are of considerable thickness, tapering, wedge-like, towards the apex; the uppermost scales are much narrower and more concave, and are less adpressed, projecting from the stem. In the axils of these small uppermost scales or bracts are borne large numbers of flowers, which are compactly arranged in a large, roundish head (Fig. 25). They are borne each on a long stalk bearing two opposite lanceolate bracteoles.

\section{Anatomy of the Stem.}

In transverse section the ground-tissue consists of cells which are more or less hexagonal or roundish in shape, and pretty compactly placed. They are full of starch-grains. There are cells here and there, especially in the epidermis, which are crammed full of immense numbers of small round bodies, probably fungal spores; in some cells these are exceedingly small, in others large and dark coloured.

The vascular bundles form a rather irregular ring; they are arranged side by side in groups, these being separated by 


\section{I28 Worsdell.-On the Comparative Anatomy of}

wide spaces in the ground-tissue. In different stems the bundles vary in number and in size; some of them are of considerable proportions, being built up of a large number of elements. Most of them have the normal orientation; some are frequently seen to have a peculiar concentric arrangement whereby the xylem comes to lie on the circumference and the phloëm in the centre; the bundle then becomes circular in outline.

The xylem-elements are few and scattered, the small protoxylem-elements lying on the innermost side of the bundle. The phloëm is largely developed, the elements being much more numerous than those of the xylem. Medullary rays and parenchyma are very abundant throughout the bundle, and add greatly to its significance. A distinct cambium is present, giving rise to secondary thickening.

In some places a small group of stone-cells lies on the outer edge of the phloëm.

Stomata occur here and there on the epidermis. They are characterized, as seen in this section, by the guard-cells being raised above the surface of the stem, the subsidiary cells also being bent upward; the former have usually dark contents.

In longitudinal section the cells of the ground-tissue are seen to be compactly placed, and undergo sliding-growth, but to a very slight extent.

The xylem-elements have oblique terminal walls, on which there is always present a round or oval perforation, occasionally two; this shows them to be vessels (Fig. 23). They are reticulately thickened and run irregularly down in more or less isolated chains. The protoxylem-elements are much elongated and narrow; the innermost have a very loose reticulate or spiral thickening.

The sieve-tubes are short elements, with transversely-placed terminal walls, on which are apparently several plates.

The companion-cells are usually of the same length as the sieve-tubes; they are either extremely narrow or broader (Fig. 24). 
In the cells of the epidermis a fungus occurs now and then, having a similar appearance to that found in the root of C. subacaulis, Gardn.

If surface-sections of the stem are made, the stomata are seen to lie in all directions, both longitudinally and transversely; in the latter case the guard-cells have a curious shape, being rounded and as broad as, or broader than, they are long; other stomata have a most peculiar oblique structure, the guard-cells, and consequently the pore, being more or less distorted and altogether abnormal in shape. The guard-cells are filled with dense granular contents, which are sometimes of a brown colour ${ }^{1}$.

In a section through the thicker portion of one of the scales, which so thickly cover the stem, the cells appear loosely arranged with small intercellular spaces amongst them ; their walls are curiously thickened at the corners where they border on an intercellular space. Brown granules occur in many of the epidermal cells. On the dorsal surface of the scale are raised stomata, as in the stem.

The bracts are of a deep orange colour.

\section{Structure of the Flower.}

The calyx is shorter than the corolla. There are no glands on its surface. It is of a deep orange colour, like the bracts. The internal tissue is not loose, but the cells fit closely together. Stomata occur on both surfaces, though they are very few in number. As regards its form, it consists of a tubular portion terminating in four or five inconspicuous lobes, which are sometimes scarcely distinguishable.

The corolla does not much overtop the calyx; it has five equal, spreading lobes. On both surfaces it is thickly covered with very large glands; the stalk of the gland is very long, consisting of six or seven elongated cells, with a very small

1 I have been kindly informed by Mr. Percy Groom that similar distorted stomata occur on the scale-leaves of two saprophytic orchids, viz. Aphyllorchis pallida and Lecanorchis moluccensis, which were described in his paper, "Contributions to the Knowledge of Monocotyledonous Saprophytes," read before the Linnean Society, December 20, I 894 . 


\section{I30 Worsdell.-On the Comparative Anatomy of}

head of one or two cells at the top. Within the stalk-cell is a fungus with buckle-joints at intervals in the mycelium, which are either quite large and round or very small. Some of the cells are filled with brown granules; very little mucilage is secreted. The corolla is pale yellow or almost white in colour; its internal tissue is loose, the cells undergoing sliding-growth.

There are four stamens, the filaments of which are covered with glands.

The anthers are all bilocular when young, becoming, as in the other species, unilocular by the rupture of the wall separating the two loculi. Each anther is curiously pointed at the base; this is owing to a prolongation of the connective, which here occurs at the base of the anther instead of near the insertion of the filament, as in the last species described. As seen in transverse section, before the dividing wall has ruptured, the anther consists of two loculi, which are often extremely narrow, owing to the large conical projection of sterile tissue into the cavity. On the ventral suture of the anther, just outside the dividing wall, occur a few cells with lignified thickenings on the walls; these belong to the second layer of the wall, the outermost layer consisting of small narrow cells.

The anther-cells are rather divaricate. The dehiscence, according to former authors ${ }^{1}$, who describe and figure it, takes place by means of a pore at the apex; this may possibly also hold good for the two previous species.

The stigma is clavate or cylindric in shape-this portion being in reality the lower of two lobes, of which the upper is dwarfed or abortive-and is drooping, owing to the style being hooked at the apex; its surface is built up of papillate cells with obtuse or rounded ends; the cell-wall at the extremity appears thicker and shows minute markings like pits; the cell contains starch and a granular substance. The ground-tissue of the stigma consists of narrow cells filled with starch-grains.

\footnotetext{
1 Wight, loc. cit.; Gardner, loc. cit.
} 
The ovary is bilocular in its lower region and unilocular above; in the latter case the placentation is parietal. In this plant the basal portions of the two bipartite placentas very nearly meet in the centre. In the lower, bilocular part of the ovary, where the projections have become united to form a dividing wall, the placentation is axile, two placentas, bearing a large number of minute ovules, projecting into each cavity.

\section{COMPARISON OF THE Forms.}

Of the three species belonging to this genus which, in the foregoing pages, have been described, two, viz., C. bicolor, Gardn., and $C$. subacaulis, Gardn., are closely allied, while the third, C. neilgherrica, Gardn., presents various characters which render it quite distinct from either of the preceding, insomuch that it has been placed by some authors in the separate genus Campbellia ${ }^{1}$.

I will first discuss the relations between the first two species described. It will have been gathered from the description that C. bicolor, Gardn., is much more typical and normal in all parts of its structure than is C. subacaulis, Gardn. This is seen, first, in the structure of the root, where the typical radial arrangement of the central cylinder and the presence of a distinct endodermal layer present a marked contrast to what we find in C. subacaulis, Gardn., where, owing to the greater reduction of the xylem and the abnormal development of the phloëm, the radial arrangement of the cylinder has become completely obscured, while no endodermal layer can be distinguished on the outside. The latter species is further distinguished by the complete absence of any local mucilaginous thickenings of the cell-wall, which is so conspicuous a feature in the cortical cells of the root of C. bicolor, Gardn.

In connexion with the more reduced form and structure of C. subacaulis, Gardn., we find the haustorial part of the rootsystem very strongly developed; in consequence of its para- 


\section{I32 Worsdell.-On the Comparative Anatomy of}

sitic habit the typical and normal anatomical structure of the roots has become extremely modified; while, as regards mass, these organs have attained a great development compared to that of the subaërial portion of the plant. C. bicolor, Gardn., has not such extreme modifications and degradations of structure to suit the parasitic habit as we find in $C$. subacaulis, Gardn. Such phenomena as the development of tubers and the branching and growth of the haustorium in various directions through the tissues of the host-root are apparently unknown in the former species.

The same reduced character is evident when the structure of the subaërial portion of $C$. subacaulis, Gardn., is examined. The stem contains numerous scattered bundles without definite arrangement or orientation-a striking difference to the regular ring of collateral bundles characteristic of the stem of $C$. bicolor, Gardn. No definite endodermis could be seen in either species. In the former plant also the ground-tissue is very loose, with a great amount of sliding-growth and contortion between the elements, constituting a largely-developed intercellular system. In C. bicolor, Gardn., this tissue is normal, and the cells compactly arranged, with few intercellular spaces.

Passing on to the appendages of the stem, we see in C. bicolor, Gardn., that the scale-leaves have a more regular arrangement than in $C$. subacaulis, Gardn. As regards the floral structure, there are a few points of difference. In the latter plant the calyx is less regularly formed, often having a mere sheath-like appearance; but the rest of the flower is built upon a larger scale; the stamens cohere when ripe, the two posterior anthers being spurred, and the stigma, which consists of a large expanded surface, is irritable-characters which do not appear in the other species.

Coming now to $C$. neilgherrica, Gardn., I will briefly mention the chief points of difference between this and the two former species, as far as the material at my disposal allows. In the reduced nature of its stem-structure, this plant occupies an intermediate position between the others; the bundles are not arranged in a definite ring, but in isolated 
portions of it, and have the ordinary collateral arrangement. The scale-leaves here are densely imbricated.

The stems of some plants of C. neilgherrica, Gardn., are remarkably swollen in places. In a section this is seen to be due to a great extension of the ground-tissue resulting from continual division of the parenchyma-cells, which at first appears to take place on one side of the stem only throughout its whole diameter. The bundles of the cylinder send branches into the newly-formed tissue; and when this portion of the stem has at length attained a considerable diameter, strands of xylem-elements are seen ramifying in all directions, not only in the outer portion of the ground-tissue, but also between the greatly enlarged bundles and throughout the pith. Thus the structure no longer bears any resemblance to that of the ordinary stem and presents a very peculiar appearance.

One distinguishing feature of this plant is the presence of two opposite bracteoles (prophylls) on the pedicel. The limb of the corolla is more spreading, nor have any of them the curious spur-like prolongation of the connective so characteristic of $C$. subacaulis, Gardn., the connective being here simply produced at the base into a short curved point. An interesting drawing of $C$. Stocksii is given by Sir. W. Hooker ${ }^{1}$, showing the structure of the anther, which is of the type here described in its dehiscence, and the character of the spur. The structure of the stigma, again, is of quite a different type : we have seen that it is not an expanded surface, as in the others, but clavate in form, the style, moreover, being hooked at the apex. The ovary differs from that of the other species in being bilocular below and unilocular above ; in the latter case, the basal part of the placenta projects far further into the cavity.

The presence of bracteoles, the structure of the anther, the stigma, and the ovary, respectively, are the chief characters by which this plant may be distinguished from the other two species. Gardner ${ }^{2}$ states that it differs from the Ceylon

\footnotetext{
Hooker, Icones Plantarum, Vol, ix, tab. 836.

${ }^{2}$ Gardner, loc, cit.
} 


\section{I34 Worsdell. - On the Comparative Anatomy of}

species in the bilabiate calyx, and in the anterior lip of the stigma being oblong, not broadly dilated.

\section{SuMMARY OF RESUlts.}

I may now bring forward the chief results accruing from the morphological and anatomical study of these three species.

The chief factor to be dealt with in these plants, and which influences their whole vegetative structure, is their parasitism. In one species, as we have seen, this mode of life has had a most marked effect, not only on the external form, but also on the internal structure of both the root and the stem, both having become adapted, chiefly in a retrogressive direction, to suit the changed habit and conditions of life of the plant.

The chief peculiarities in these plants, which may be considered as the outcome of their parasitic habit, are the following: the branching and anastomising root-system, from which the flowering-stems are produced; the rhizomelike character of the root, and the absence of root hairs; the development (in one species) of tubers, from which the haustoria and the young lateral roots and stems are produced, and which serve as storehouses for the nutrition of the plant; the modified anatomical structure of the cylinder of the root, in which the xylem has become reduced and the phloëm correspondingly developed; and the reduction of the conducting-tissue of the stem, co-related with the absence of foliage leaves, which are here replaced by scales.

The most abnormal and interesting feature occurring in these plants is presented by the subterranean portion of C. subacaulis especially, which, on investigation, is discovered to consist of organs having the character of roots, though their morphological nature is well concealed, owing to their extreme modification arising from the parasitic habit.

The tubers, which arise at intervals in the root-system of the plant just named, are the most important parts of it, for it is from these that the haustoria are chiefly formed, while they also act as reservoirs of nutriment for the whole plant.

The haustorium is interesting as having an exogenous origin, 
and not an endogenous one, as described for many other parasites; it agrees in this respect with that of Rhinanthus.

The young lateral roots and stems have both a similar origin from the parent-root ; they arise endogenously and from the central cylinder; as they increase in age, this origin becomes more and more obscure, till it becomes a rather difficult task to determine whether it is a case of endogeny or exogeny.

The degradation of structure in these plants we can trace through the stem and the foliar appendages up to the calyx, with which it ceases. The rest of the flower is chiefly distinguished by the mucilaginous covering of the corolla, the two spurred posterior anthers, and the motile stigma, the first and last characters, however, applying to one of the species only.

This work has been carried out in the Botanical Laboratory of the Royal College of Science, South Kensington. I must express my warmest thanks to Professor J. B. Farmer, who collected the plants in their native habitat, for so kindly placing the material at my disposal for investigation, and also for the great assistance which he has continually afforded me throughout the progress of the work. I am also much indebted to him for the drawings of Figs. I, 15,16 , and $\mathrm{I} 7$.

\title{
EXPLANATION OF THE FIGURES IN PLATES $\mathrm{V}$ AND VI.
}

\author{
Illustrating Mr. Worsdell's paper on Christisonia.
}

Fig. I. Entire plant of $C$. subacaulis, Gardn., showing the disposition of the root, stems, and flowers.

Fig. 2. Portions of the subterranean part of C. subacaulis, Gardn., showing the mode in which the roots anastomose together to form a tangled network. $\times I_{2}^{\frac{1}{2}}$. 


\section{Worsdell.-On the Genus Christisonia.}

Fig. 3. A tuberous portion $(t b)$ of the root of C. subacaulis, Gardn., showing its attachment to the root of a Bamboo. $\times 2$.

Fig. $4 a$. Transverse section throtigh the central cylinder of the root of $C$. subacaulis, Gardn. $\times 75$.

Fig. 4 b. Transverse section through the root of $C$. bicolor, Gardn. $x=$ xylem; $p h=$ phloëm; $s n=$ stone-cells ; $c t=$ cortex. $\times 75$.

Fig. 5. Transverse section of a 'proteid-bundle' from a tuber of $C$. subacaulis, Gardn. $\times$ I00.

Fig. 6. Haustorium of C.subacaulis, Gardn., penetrating root of Bamboo. $\times \mathbf{I} 30$.

Figs. 7, 8, 9. Portions of transverse sections through a branch of a haustorium of C. subacaulis, Gardn., showing mode in which suckers grow out from the innermost cells and dissolve their way into the central cylinder $(c c) . \quad \times 260$.

Fig. Io. Section of a haustorium of C. subacaulis, Gardn., which has branched, the branches running parallel to the central cylinder of the host-root. $\times 65$.

Fig. I I. Apex of a root of $C$. subaiaulis, Gardn. $r c=$ root-cap; $d t=$ dermatogen. $\times 100$.

Fig. I2. Longitudinal section of the stem and root of $C$. subacaulis, Gardn., showing the anastomosis of the bundle-system in the two organs (diagrammatic).

Fig. I $2 a$. Transverse section of the root and longitudinal section of the stem, showing the same (diagrammatic).

Fig. I3. Gland from the stem of C. subacaulis, Gardn.

Fig. 14. Single stoma in section. $\times 260$.

Fig. I5. Flower of $C$. subacaulis, Gardn., seen from the front with part of the corolla removed, showing stamens and stigma.

Fig. I6. Side view of flower.

Fig. I7. Flower with the floral envelopes removed, showing the coherence of the stamens and the stigma.

Fig. I8. Portion of a root of a species of Strobilanth, showing the attachment of several small plants of $C$. bicolor, Gardn. $\times 2$.

Fig. 19. Part of transverse section of the root of $C$. bicolor, Gardn., showing the origin of a rootlet. $\quad r c=$ root-cap; $c c=$ central cylinder of parent-root. $\times 6_{5}$.

Fig. 20. Longitudinal section of a root of C. subacaulis, Gardn., showing the origin of a stem. $l=$ first two young foliar organs ; $i c=$ central cylinder of parentroot. $\times 50$.

Fig. 2I. Part of transverse section of a root of C. bicolor, Gardn., showing the place of origin of a haustorium $(h r) . \quad \times 50$.

Fig. 22. Transverse section of the root of $C$. bicolor, Gardn., and root of Strobilanth, showing exogenous mode of origin of haustorium; also the zone of starch-containing cells in cortex of parasite (slightly diagrammatic). $\quad \times 100$.

Fig. 23. Part of a vessel from the stem of $C$. neilgherrica, Gardn. $\quad \times 260$.

Fig. 2+. Sieve-tube and companion-cell from the stem of $C$. neilgherrica, Gardn. $\times 260$.

Fig. 25. Stem and inflorescence of $C$. neilgherrica, Gardn.

Fig. 26. Cortical cell from the root of C. subacaulis, Gardn., showing the fungus growing on one of its walls. $\times 260$.

Fig. 27. An intercellular space with the fungus forming conidia. $\times 260$. 

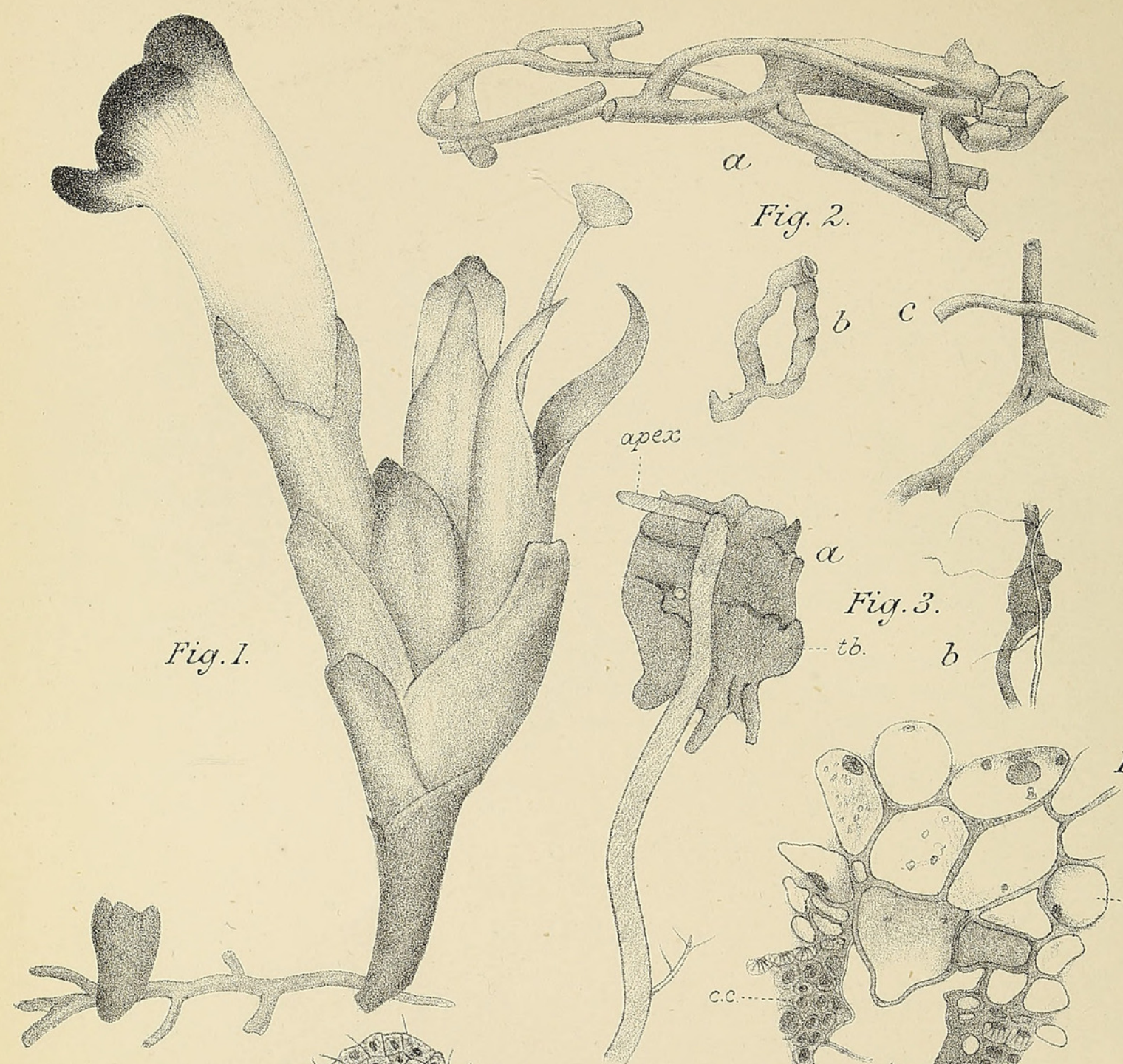

Fig.
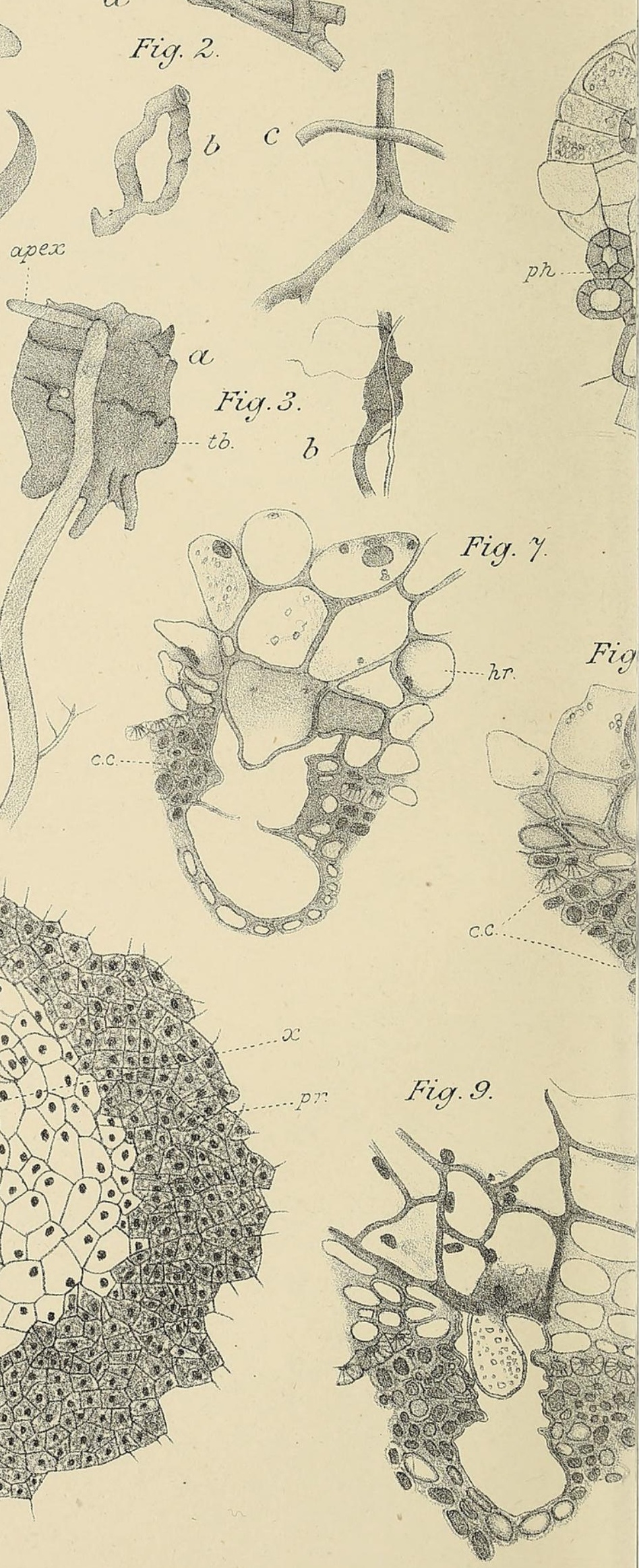


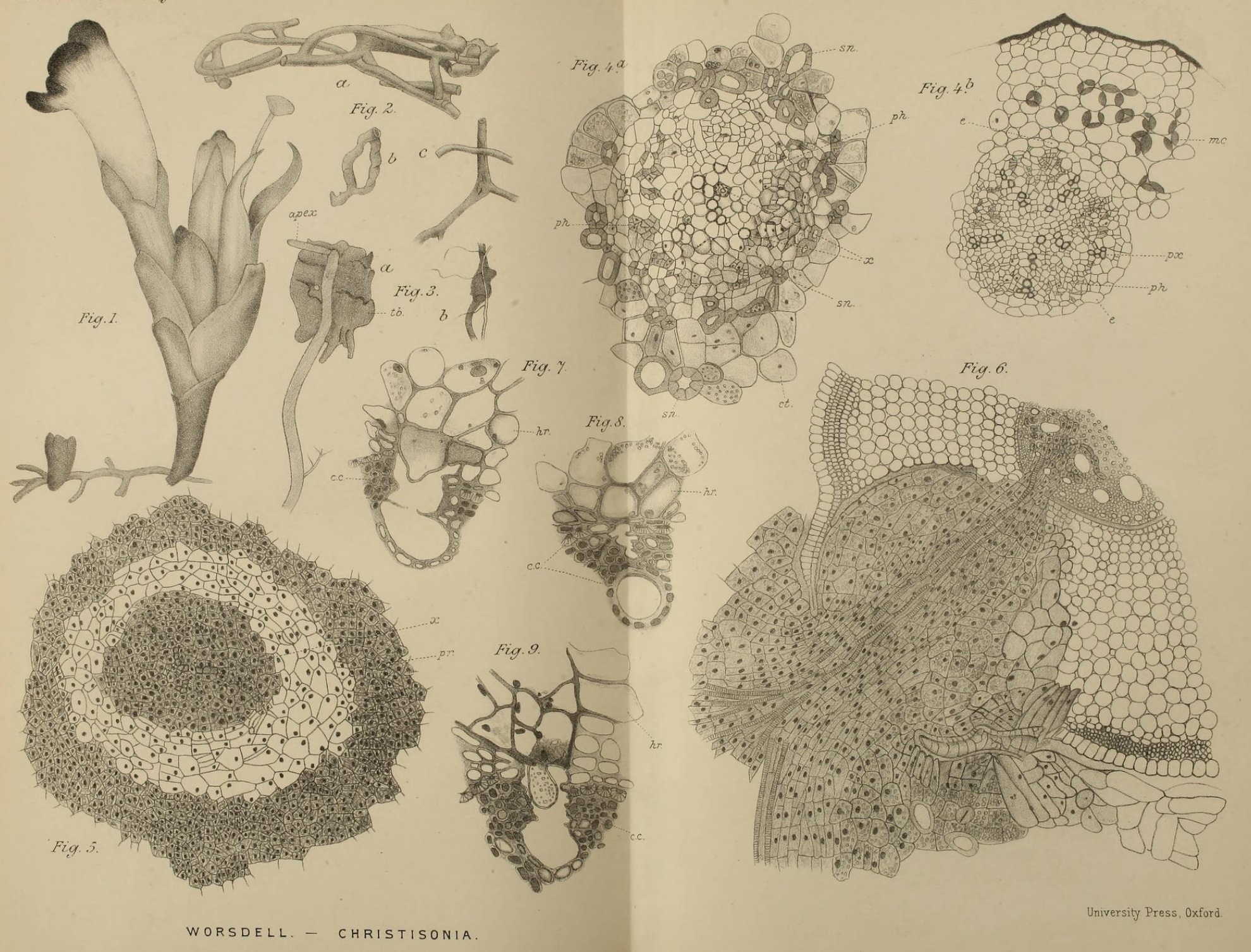




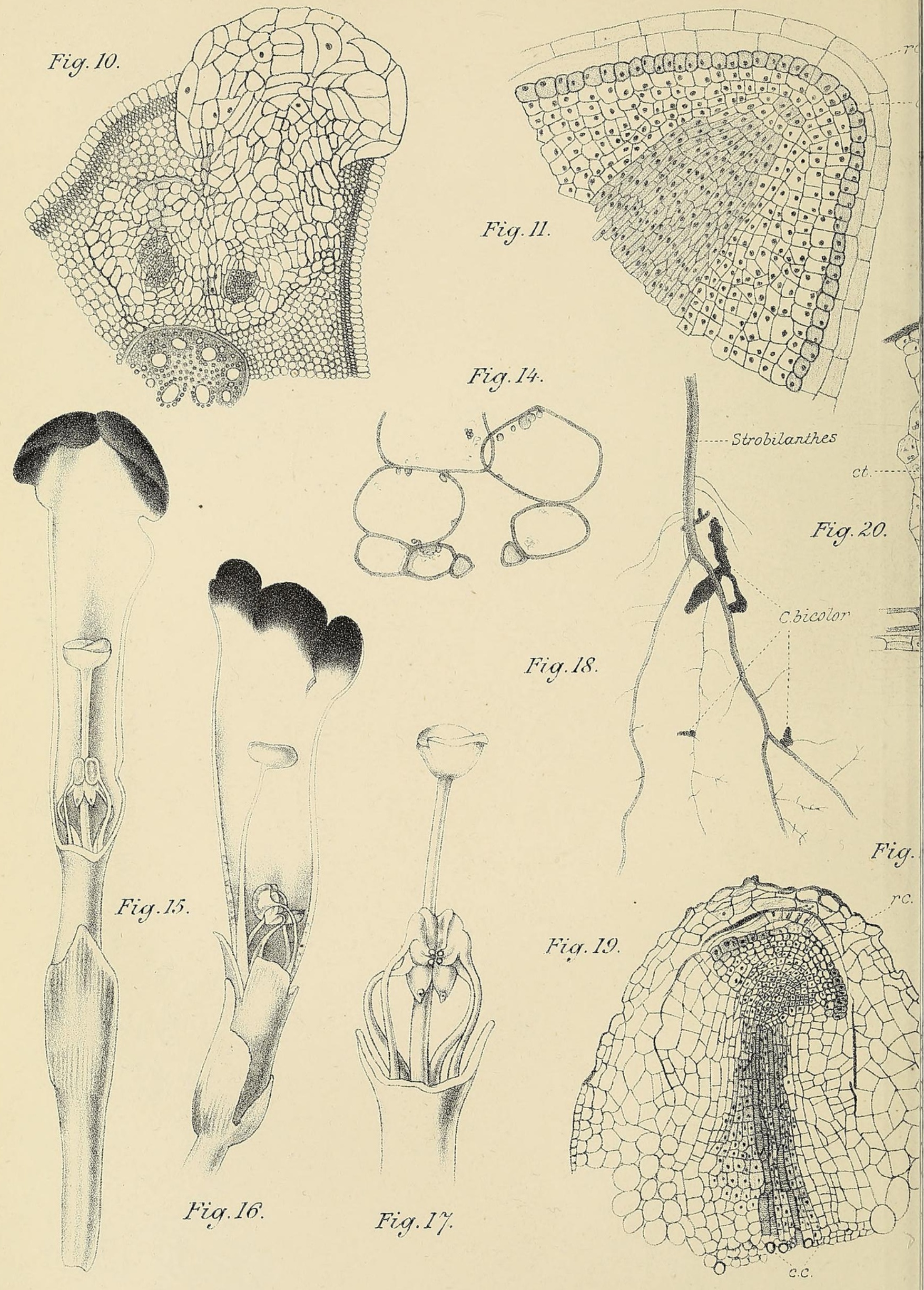

WORSDELL. - CHRISTISONIA. 
Vol. IX, PI.VI.

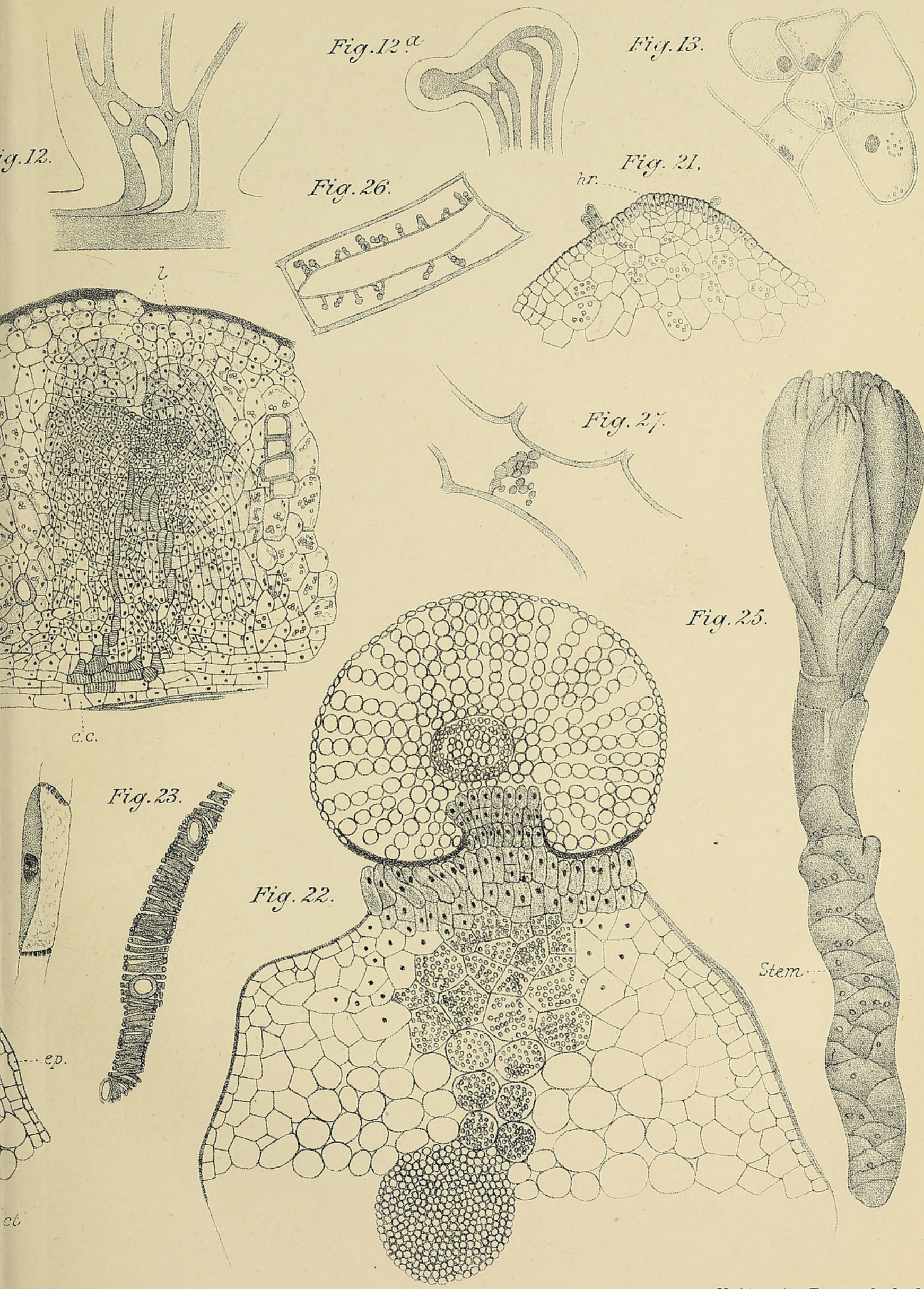

University Press, Oxford. 


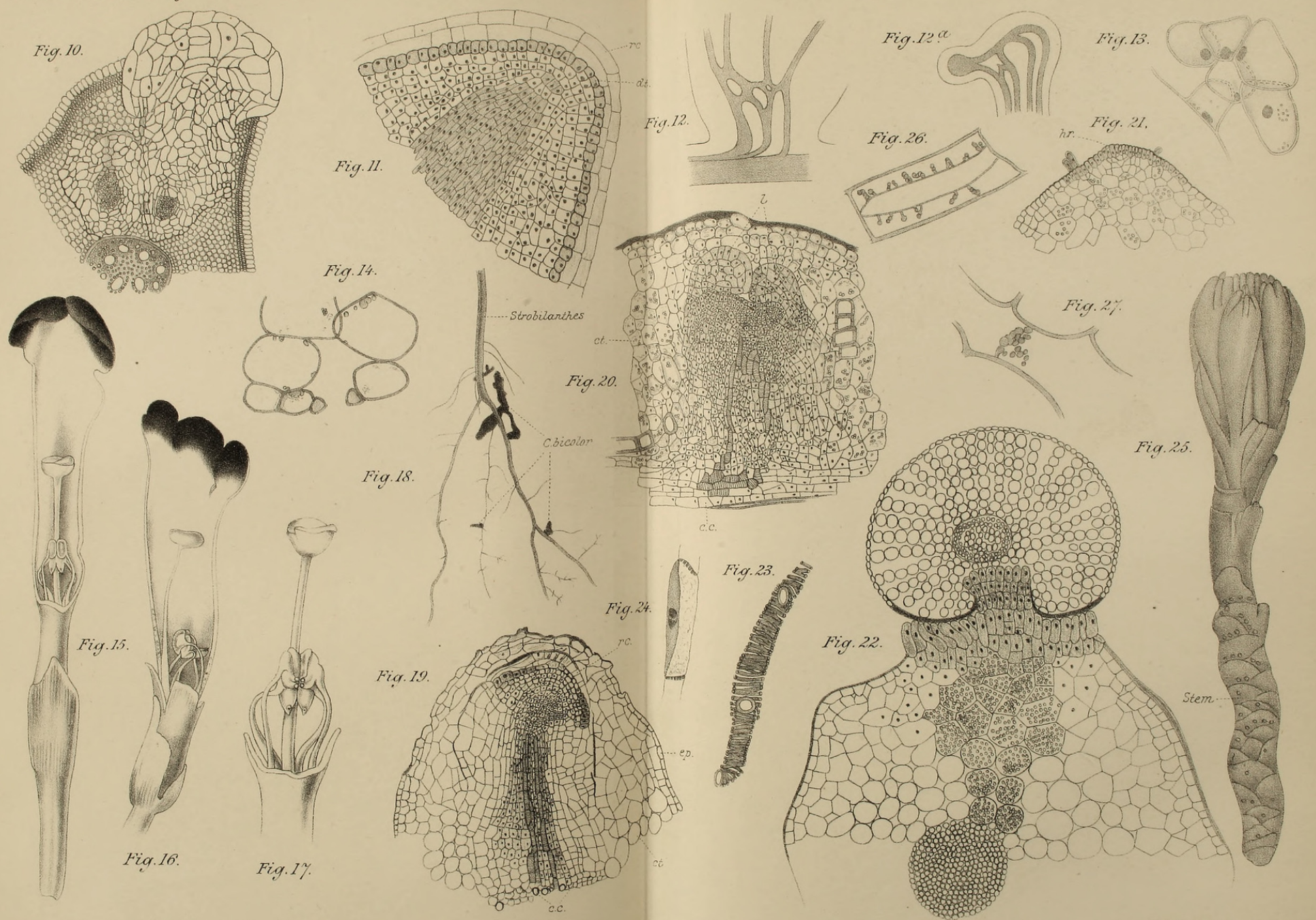




\section{$2 \mathrm{BHL}$ Biodiversity Heritage Library}

Worsdell, Wilson Crosfield. 1895. "On the comparative anatomy of certain species of the genus Christisonia." Annals of botany 9, 103-136. https://doi.org/10.1093/oxfordjournals.aob.a090725.

View This Item Online: https://www.biodiversitylibrary.org/item/233478

DOI: https://doi.org/10.1093/oxfordjournals.aob.a090725

Permalink: https://www.biodiversitylibrary.org/partpdf/318368

\section{Holding Institution}

Smithsonian Libraries

\section{Sponsored by}

Biodiversity Heritage Library

\section{Copyright \& Reuse}

Copyright Status: Not in copyright. The BHL knows of no copyright restrictions on this item.

This document was created from content at the Biodiversity Heritage Library, the world's largest open access digital library for biodiversity literature and archives. Visit BHL at https://www.biodiversitylibrary.org. 